\title{
Pickworthiidae and Aqabarellidae New Family (Caenogastropoda, Mollusca) of Aqaba, Jordan: Their Larval Shells and Remarks about Their Evolution and Relation
}

\author{
Ikhlas Alhejoj1*, Klaus Bandel², Tariq Al-Najjar ${ }^{3}$ \\ ${ }^{1}$ The University of Jordan, Department of Geology, Amman, Jordan \\ ${ }^{2}$ Universität Hamburg, Geologisch-Paläontologisches Institut und Museum Hamburg, Hamburg, Germany \\ ${ }^{3}$ The University of Jordan, Aqaba-Jordan/Aqaba Branch, Faculty of Marine Sciences, Aqaba, Jordan \\ Email: *ekl_hjouj@yahoo.com, *i.alhejoj@ju.edu.jo
}

How to cite this paper: Alhejoj, I., Bandel, K. and Al-Najjar, T. (2016) Pickworthiidae and Aqabarellidae New Family (Caenogastropoda, Mollusca) of Aqaba, Jordan: Their Larval Shells and Remarks about Their Evolution and Relation. Natural Science, 8, 403-430.

http://dx.doi.org/10.4236/ns.2016.89044

Received: March 17, 2016

Accepted: September 26, 2016

Published: September 29, 2016

Copyright $\odot 2016$ by authors and Scientific Research Publishing Inc. This work is licensed under the Creative Commons Attribution International License (CC BY 4.0).

http://creativecommons.org/licenses/by/4.0/

\begin{abstract}
Among small sized gastropods found in Aqaba (Jordan), Sansonia occurs relatively common with Sansonia cebuana which is recognized from the the fringing reef near the Marine Biological Station at Aqaba, while Mecoliotia and Chrystella are rare. Mecoliotia aqabaensis $\mathrm{n}$. sp and Chrystella shinaqi n. sp are described with the later resembling Chrystella finckhi. They are compared with other members of the Pickworthiidae, of which a new species of Discrevina from Indonesia is described. A species of Aqabarella new genus resembles in shape of its teleoconch members of the Pickworthiidae but its protoconch is distinct in ornament of the larval shell and shape of the aperture and it is placed in it own family, Aqabarellidae. Aqabarella urdunensis is relatively more common than the rare Aqabarella pulchella. Similar larval shells are found in Vanikoridae, Planaxidae and Cerithiidae, those of Littorinidae and Rissoidae are more distinct and all of them differ from those of the Aqabarellidae, while some ancient small species from the Triassic tropical Tethys had a similar protoconch.
\end{abstract}

\section{Keywords}

Mollusca, Caenogastropoda, Pickworthiidae, Aqabarellidae, Aqaba, Tethys, Triassic

\section{Introduction}

The aim of the study is to describe the gastropod species from Aqaba as they occur near the Marine Biology Station of Jordan at Aqaba with special emphasis of the shape and 
ornament of their larval shell. The fauna found in Aqaba resembles that generally found in the tropical Indo Pacific but with a selection of such species which have a planktotophic larval development. It is thus not expected that the here newly described species occur only in the Gulf of Aqaba, but have a wider occurrence not only in the Red Sea but also in other parts of the Indo-Pacific Ocean. Thus one species is included that lives in similar surrounding and has similar shell shape and size from Satonda Island on the Great Barrier Reef of Australia. While the shape and ornament of the larval shell of five of the here described species has characters as are known among the Pickworthiidae, two species differ and are here placed in an own, new family. The characters of the larval shell allow distinguishing as own and independent group the two species of Aqabarella.

The genus Sansonia Jousseaume, 1892 had been considered to represent a synonym to Pickworthia Iredale, 1917 [1] [2] and that had been accepted since. The type to the genus Sansonia is Iphitus tuberculatus Watson, 1886 from the Caribbean Sea ([3], Figure 1833). This species had also been placed with Mecoliotia Hedley, 1899 [4]. Another similar species to the type species of Sansonia from the tropical Atlantic had been proposed with the genus Mareleptopoma Moolenbeek \& Faber, 1984, and several species have since been placed in that genus which could actually be determined as Sansonia as well [5] [6].

Alongside the common Sansonia cebuana three other species have been found but more rarely in the fringing reef near the Marine Science Station at Aqaba. One belongs to the genus Mecoliotia Hedley, 1899 and two to the genus Chrystella Laseron, 1957. They differ in regard to the teleoconch shape from that of Sansonia but have very similar protoconchs. Their larvae were more rarely recognized from the plankton that had been caught during the years 2002 to 2010 .

Two small sized species at first were thought to belong to the Pickworthiidae since they are also small and of similar shell shape and the aperture has a thickened margin. But they have a distinctly different shape of protoconch. Compared to the Pickworthiidae, they evidently belong to another group of Caenogastropoda, here placed in the Aqabarellidae nov. fam. Their protoconch resembles that of some species which have been recognized from a number of fossil species ranging back to the Carboniferous. The Pickworthiidae Iredale, 1917 hold quite a number of species [5] [7]-[11]. The paleontological history of the family has also become known to some degree [12] [13]. Here we describe the species from Aqaba and discuss their place among their recent and fossil relatives.

\section{Taxonomic Description}

\section{Family Pickworthiidae Iredale, 1917}

The small sized gastropods which belong in the Pickworthiidae have low to high teleoconch shape connected to a characteristic barrel shaped larval shell that is provided with a strong projection of its outer lip. The shell of the species of the Pickworthiidae is around 0.5 to $5 \mathrm{~mm}$ in size when fully grown. Ornament of the larval shell consists of 
spiral ribs and may also have ribbons of short axial ribs crossing them [8]-[12] [14]. In case of lecithotrophic development the protoconch is simplified and loses its characteristic shape and ornament [5] [8] [9]. The teleoconch consists of few high to low conical whorls and ends in a rounded aperture that is thickened at its edge. Its ornament consists usually of straight axial and spiral ribs. The four species of the Pickworthiidae from Aqaba described below can be placed in three genera, Sansonia, Mecoliotia and Chrystella.

Remarks: The taxon has been created around the genus Pickworthia Iredale, 1917 from the Australian Pacific which represents a synonym of the genus Sansonia Jousseaume, 1892 [3]. Sansonia was placed among the Rissoidea Gray, 1842, Tornidae Sacco, 1895 (=Adeorbidae Monterosato, 1884). But is has also been suggested that the Pickworthiidae may be a family of the Littorinoidea Children, 1884) [15]. Regarding their protoconch morphology they resemble somewhat that of some tropical Littorinidae, but also have similar shapes among the Cerithioidea [14]. Pickworthiidae were suggested to represent an own family within the superfamily Littorinoidea [16]. Members of the Pickworthiidae are united by the shape and ornament of their protoconch, in case the species here describes they have a planktotrophic stage in their ontogeny. This shape and ornament has been similar since Early Paleocene (middle Danian) [12]. The family has therefore been shown to have been in existence for at least 60 Million years in temperate and tropical seas.

Sansonia hedegaardi Bandel \& Kowalke, 1997 from the Early Paleocene of Denmark with a depression below their suture resembles a slender Microliotia Boettger, 1902 of the kind as in case of Microliotia suturalis Kase, 1998 from the Philippines ([9], figs. 20-21). Sansonia hedegaardi has characters intermediating between Pickworthia and Reynellona Iredale, 1917 in the shape of its teleoconch (shell of the fully grown individual), while the protoconch (shell of the embryo and larva) is quite like that of Sansonia ([12], pl. 5, figs. 2, 5). Gania Bandel \& Kowalke, 1997 from the Eocene of France is characterized by a relatively short shell. In case it would have a more slender shell it would change into Chrystella Laseron, 1957. Among known Cretaceous species the teleoconch of Urceolabrum Wade, 1916 resembles that of species of Pickworthiidae ([17], pl.1 figs. 13-17, pl.2, fig. 3). Its small trochiform teleoconch with prominent nodes on the axial ribs and strongly thickened round aperture resembles that of Microliotia, but the protoconch is of slender shape with smooth larval whorls. It can, therefore, not be placed with the Pickworthiidae [8]-[11]. The place of Urecolabrum with similar morphology of its teleoconch is due to convergence [5].

It has been suggested that 9 living genera to compose the Pickworthiidae [7], but also up to 11 genera have been included in the checklist in addition to the fossil Gania. The protoconch of members of the Pickworthiidae consists "of two convex whorls, sculptured by two to ten granular spiral cords, ending in a deep notch" [7]. This characterization is not sufficiently detailed ([12], pl. 4). Not all of the species with planktotrophic larva (Plankton feeding stage as free swimming larva) have a shell of two whorls and an ornament with simple spirals. Sansonia cebuana Bandel \& Kowalke, 1997, for example, 
has a protoconch consisting of three whorls and an ornament of the larval shell with spiral lines and rows of axial ribs. On the other side a simplified shape of the protoconch has been documented in case of species which have a more lecithotrophic embryonic development [5] [8].

The family Pickworthiidae Iredale, 1917 has been interpreted to be related to the Reynellonidae Iredale, 1917 [18] [19]. The group is in existence at least since Paleocene [12] it has been quite conservative in regard to the shape and ornament of its larval shell. The teleoconch in contrast documents the change from the original short conical to rissoiform shell as found in Sansonia hedegaardi and Gania carinata in the Paleogene to slender species of Chrystella with spiral ornament as in Gania to conical and rissoiform species of Sansonia-Pickworthia-Reynellona-Discrevinia, short rounded or triangular shape as in Mecoliota and Microlitia with conical shell and Ampullosansonia and Tinianella with rounded shell to flattened ones as in Astrosansonia Le Renard \& Bouchet, 2003. The later lived in the sea that covered much of France during the Miocene. This sea was interpreted to have been in contact with the Indo-Pacific ([13], pl. 5, fig. 12). The protoconch of a Astrosansonia dautzenbergi (Bavay, 1917) from French Polynesia ([7], fig. 5.101.F.G) is similar to that of Sansonia cebuana (Bandel \& Kowalke (1997, pl. 4, fig. 6) and its ornament was considered close to ornaments found among Cerithioidea and Littorinoidea. This protoconch also distinguishes very clearly from that of Aqabarella by higher shell shape and much less ornament of the larval shell.

\section{Genus Sansonia Jousseaume, 1892}

Diagnostic characters: Small turbinate shell with apical angle around $50^{\circ}$, about 5 teleoconch whorls with flat base and ornament of spiral rows of tubercles. The round aperture has a thickened margin. The protoconch is barrel shaped with embryonic whorl with faint ornament of pits surrounded by ridges and the larval shell with spiral lines. The aperture projects with its outer lip forming an angular tongue. The type of the genus is Iphitus tuberculatus Watson, 1886 from the Caribbean Sea.

Description: The shell is smaller than $2 \mathrm{~mm}$, turbinate with a high spire and flattened whorls. The outer lip of the fully grown individual is thickened and forms rim around the aperture a strong varix. Ornament consists of three rows of large, rounded beads and the base has a row of beads around the narrow umbilicus ([4] fig. 1, [20] fig. 414a). The larval shell of the protoconch has barrel shape and is ornamented by spiral lines. It is $0.16 \mathrm{~mm}$ high and $0.13 \mathrm{~mm}$ wide, and ends with a large projection on the outer lip of its aperture. The embryonic whorls is about $0.1 \mathrm{~mm}$ wide and the following 1.5 whorls of the larval shell are rounded and ornamented by about five fine spiral lines or rows of tubercles of different thickness ([12], pl. 4, fig. 5).

This protoconch is attached to a teleoconch with apical angle of about $50^{\circ}$. The shell consists of 5.5 whorls of the teleoconch each bearing two rows of rounded beads and a narrow beaded keel above the suture in the specimen from Yucatan. Here the flat base bears a row of beads bordering a slit like umbilicus and the round aperture has a thickened lip. The final whorl of the shell can cover the last row of beads and ornament of the earlier whorls in that case shows on two rows of beads ([3], fig. 1833). 
The species of the Sansonia which have been accepted as valid are Sansonia alisonae Le Renard \& Bouchet, 2003; Sansonia andamanica (Preston, 1908); Sansonia cebuana Bandel \& Kowalke, 1997; Sansonia costata Kase, 1998; Sansonia halligani (Hedley, 1899); Sansonia hilutangensis Bandel \& Kowalke, 1997; Sansonia iejimensis Kase, 1998; Sansonia kirkpatricki (Iredale, 1917); Sansonia nuda Kase, 1998; Sansonia shigemitsui Kase, 1998; Sansonia sumatrensis (Thiele, 1925); Sansonia tuberculata (Watson, 1886) [21].

Plate 1: Fully grown shell of Sansonia cebuana seen in apertural view (1) and from the back (2) is approximately $1 \mathrm{~mm}$ high and provided with the protoconch (3) that consists of embryonic and larval shell. Larvae ready from metamorphosis with the projection of the outer lip and a size of $0.2 \mathrm{~mm}$ in height (4) and with embryonic whorl smooth and ending with the first growth lines (5) succeeded by larval ornament of spiral rows, which in the first whorl grown by the larva have low components, and on the second whorl of the larva stronger ones which form keels with ornament of nodes. The end of larval growth is represented by a thickened margin of the aperture (6).

\section{Species Sansonia cebuana Bandel \& Kowalke, 1997}

Plate 1: figs. 1-6, Plate 2: figs. 1-4.

Diagnostic characters: Individuals of Sansonia tuberculata from the Caribbean Sea at Yucatan Peninsula are considered close to the type [20]. In case of Sansonia cebuana the protoconch differs in details of the larval shell. Here the upper row of nodules connects to short axial ribs. The second spiral rib is the periphery. Further spiral lines are present and the aperture project in an angular lobe of its outer lip. The teleoconch has about three whorls ornamented by numerous axial ribs and one to three spiral ribs. The aperture is round and its margin is thickened.

Description: The protoconch of Sansonia cebuana from Aqaba is about $0.2 \mathrm{~mm}$ high and consists of three whorls. It ends with a very long projection from the middle of the outer lip of its aperture. The larval shell has a sculpture of spiral ribs, of which the first lies below the suture, the second forms the peripheral edge. The rib below the suture bears tubercles and is connected to a row of short axial ribs. The peripheral spiral rib is crossed by numerous short axial ribs. The whorl side is a little concave or it is plane and there are 2 to 3 spiral lines near and just above the suture.

The whorl succeeding the $0.08 \mathrm{~mm}$ wide embryonic shell is covered by sinuous growth lines. Here the first spiral ribs insert. The protoconch may be attached with slight inclination to the teleoconch or it may be upright and coiled around the same central axis as the whorls of the teleoconch.

The teleoconch is only about $1 \mathrm{~mm}$ high and commonly consists of a little more than three whorls with apical angle of about $50^{\circ}$ to $55^{\circ}$. The first whorl of the teleoconch has one strong central keel that later on becomes the spiral rib above the suture and at the corner to the base. About 10 to 12 axial ribs are present here. Their number increases to about 16 on the second whorl, and about 20 on the third whorl. The second whorl has two spiral ribs and the third may have three spiral ribs. The lower of these ribs can be covered up by the succeeding whorl. The ornament of the body whorl consists of six 
spiral ribs of which three are on the rounded base. They become covered by the succeeding whorl and one lies in the suture and may or may not be covered by it. One ridge surrounds the narrow umbilicus. The whorls are almost flat between the spiral rows of beads that form where the axial ridges.

In some cases the ornament of the last or last two whorls consists only of low ridges (Plate 2, figs. 1 and 4). Fully grown individuals may have only 3 whorls of the teleoconch while others have up to four whorls. With four whorls the shell measures about $1.3 \mathrm{~mm}$ in height. Sometimes shell is added to the thickened margin of a body whorl since shell growth continued for up to another half whorl (Plate 2, fig. 2). Also the number of spiral ribs on the base differs between three and four. In case a fourth whorl is added this whorl is more rounded than usual. The aperture of the fully grown shell is thickened and almost perfectly round. The base is either pierced by a narrow umbilicus that may also be slit-like or not present at all. Color of the shell is light brown to white and may be the same in the protoconch as in the teleoconch, but usually the protoconch is brown.

The small gastropod lives among hard substrates in the reef and on the reef flat. It occurs very commonly in Aqaba within and near the fringing coral reef. Also its larvae have regularly been caught in the plankton.

Plate 2:

Fully grown shells of Sansonia cebuana with a variety with reduced ornament (fig. 1) and the other with reduction of rib pattern only in the last half whorl of its shell, and one documenting change in ornament as well as slight deviation from regular coiling mode (figs. 2 and 4) (shell approximately $1 \mathrm{~mm}$ high). Change in coiling mode of the adult shell can occur without break in growth (fig. 2), or after interruption of growth (fig. 4). The protoconch is attached to the teloconch with a slight change in the coiling axis (fig. 3). The fully grown shell of Mecoliotia aqabaensis (fig. 5) is broadly conical and approximately $1.5 \mathrm{~mm}$ wide and high. The protoconch consists of rounded whorls (fig. 6) with smooth embryonic shell and the larval shell with spiral ornament of lines and rows of tubercles (fig. 6). The teleoconch consists of 3.5 whorls with ornament of axial and spiral ribs forming a regular pattern of rectangles.

Remarks: The protoconch of Sansonia cebuana from Aqaba differs from that of Sansonia tuberculata by having a more pronounced axial ornament. Sansonia andamanica Preston, 1908 is similar but appears to have a smaller protoconch and one more whorl of the teleoconch when compared with Sansonia cebuana. Sansonia tuberculata collected in the northern Red Sea had been determined as Mareleptopoma n. sp ([22], pl. 12, figs. $7 \mathrm{a}, \mathrm{b}, 8 \mathrm{a}, \mathrm{b})$. It was suggested that this species had been described before ([23], pl. 15, figs 8, 9a-d) under the name Sansonia (Sansonia) christinae Selli, 1973 which is considered a synonym of Sansonia kirkpatricki (Iredale, 1917) [5]. This Mareleptopoma $\mathrm{n}$ sp. is the most common representative of the Pickworthiidae on the reef slope and in sand between coral patches near Safaga in the northern Red Sea. The species had been described earlier [12] [21] [24].

Individuals documented from the shallow Sea near Satonda, Indonesia, belong to a 
species with quite the same shell as found in Aqaba. Sansonia cebuana from the shallow sea at Cebu (Philippines) and Sansonia hilutangensis Bandel \& Kowalke, 1997 from the same locality regarding the shape of the teleoconch and its ornament are quite similar, while the protoconch distinguishes them from each other. Sansonia cebuana has a protoconch with about three whorls ([12], pl. 4, figs. 3 and 6), while that of Sansonia hilutangensis consists of a little more than two whorls and is less ornamented ([12], pl. 4, figs. 2, 7). It is very close in shape to Mareleptopoma minor from the Pliocene of Spain and to Sansonia shigemitsui Kase, 1998 [6]. It is possible that Sansonia hilutangensis and Sansonia shigemetsui represent the same species and are synonyms. The protoconch also distinguishes from Sansonia iejimensis Kase, 1998 and Sansonia costata Kase, 1998 which live in submarine caves in the Pacific Ocean. They have a more rounded protoconch of only 1.5 whorls ([12], figs. 1-3). This indicates that the species had a more lecithotrophic (yolk-rich) embryonic development than is the case in Sansonia cebuana.

Sansonia kenneyi (Ladd, 1966) from the Oligocene of France ([12] [24], pl. 10, figs 10-11) may actually not represent the same genus and had originally been considered to belong to the rissoid genus Alvania from the Miocene of Bikini Island ([25], pl. 12, fig. 3). The fossil species from the Oligocene has a $1 \mathrm{~mm}$ high shell consisting of three whorls of the teleoconch of quite the same ornament as in Sansonia cebuana, but the protoconch has 2.5 whorls and ornament of spiral ribs without axial components on the larval whorls.

Species of Pickworthia Iredale, 1917 have the apical angle of the teleoconch whorls with less than $40^{\circ}$ and the adult shell consists of more whorls as found in Sansonia. Sculpture consists of axial as well as spiral elements. The type is Pickworthia kirkpatricki Iredale, 1917 from the sea at Australia ([7], fig. 15.101A).

Mareleptopoma Moolenbeek \& Faber, 1984 has a more rounded body whorl than Sansonia and ornament of the larval shell consists about 10 spiral lines ([26], figs 47-48). The genus is based on Mareleptopoma karpatensis Moolenbeek \& Faber, 1984 from the Caribbean Sea near Bonaire. Teleoconch as well as the protoconch of Mareleptopoma thus differ from those of Sansonia.

Sansonia tuberculata (Watson, 1886) closely resembles Sansonia italica [6] [27] (figs 1-2) and was considered a synonym to the species Mareleptopoma minor (Almeria \& Bofill, 1898) (originally as Danilia. It was suggested to place Sansonia hedegaardi from the Paleocene into the genus Mareleptopoma) [6] [13]. Mareleptopoma badenicum Janssen, 2004 from the Mid Miocene of the Paratethys was considered as possible ancestor to Sansonia italica. This species that is also Mareleptopoma minor still lives at Cabo Verde Archipelago and had been living in the Mediterranean Sea during the Pliocene [6] [28]. According to their illustration the teleoconch of Mareleptopoma minor is quite similar to that of Sansonia cebuana but the protoconch has half a whorl less. Mareleptopoma badenicum, Mareleptopoma lychoviense (Krach, 1981), Mareleptopoma toriferens according to the shape, ornament and size of their teleoconch fall into the varieties found in case of Sansonia cebuana from Aqaba [13] (pl. 2, figs 3-6, pl. 3, fig. 7). 
These fossil species from the Miocene differ in regard to the ornament and composition of the protoconch that consists of only 2.5 whorls with only ornament of spiral lines on their larval whorls.

Mareleptopoma spinosa (Hedley, 1902) from Cebu closely resembles the illustration of Mareleptopoma spinosa from the Solomon Islands ([7], fig. 15.101C). It is much shorter than Sansonia and has an apical angle of about $60^{\circ}-70^{\circ}$. The protoconch consists of 2.3 whorls and is ornamented by about 6 spiral lines, some of which are composed of tubercles. With Mareleptopoma vaubani Le Renard \& Bouchet, 2003 a species was included in Mareleptopoma that is short and has a wide apical angle as may be found in Mecoliotia, but in contrast to that genus it has rounded whorls. For this species a new genus would have to be proposed, since the differences in shell shape could be considered diagnostic to a distinct genus of the Pickworthiidae.

\section{Genus Mecoliotia Hedley 1899 (=Microliotia Boettger, 1901)}

Mecoliotia has a conical short shell with apical angle about $60^{\circ}$ or larger with its teleoconch ornamented with spiral and axial ribs which at cross-points are raised into nodes. The umbilicus is open and the base ornamented by several spiral ribs. The base ends in an edge or keel and base and flank of whorls are somewhat flattened. The type is Mecoliotia halligani Hedley, 1899 from Pacific Ocean near Funafuti Island ([3], fig. 1832).

Remarks: Mecoliotia differs from Sansonia by having a wider teleoconch and an umbilicus ([29], fig. 160). Its coarser ornament with axial and spiral ribs distinguishes from the fossil Microliotia Boettger, 1901 ([13] pl. 1, fig. 1). The illustration of Mecoliotia presented by [3] closely resembles the figure of Mareleptopoma spinosa (Hedley, 1902) as presented by ([7], fig. 15.101C). The presented drawing from a species coming from the Solomon Islands may perhaps represent Mecoliotia halligani. The documented protoconch with spiral ornament but little detail considered Mecoliotia and Microliotia were interpreted to represent synonyms ([7], fig. 15.101B). Mecoliotia halligani may be close to or the same as Microliotia saturnia from Australia [7]. Microliotia saturnia from Queensland differs from Mecolitia halligani by having three instead of two spiral ribs on their body whorl. This species does not occur in the list of species of living Pickworthiidae [5]. It differs from Microliotia saturnalis Kase, 1998 by being shorter and having a wider apertural rim in the last whorl ([9], figs. 19-21).

Plate 3:

The broadly conical, white shell of Mecoliotia aqabaensis is ornamented by axial and spiral ribs forming a regular pattern of rectangles. The periphery is angular and the round aperture has a wide rim with fine lines (fig. 1). The umbilicus is conical. The apical angle of about $80^{\circ}$ and the shell is $1.5 \mathrm{~mm}$ high and wide consisting of 3.5 whorls of the teleoconch (fig. 2). A smooth embryonic whorl is succeeded by the larval shell with ornament of spiral rows of tubercles and spiral lines (figs. 3 and 4 ). The protoconch measures $0.3 \mathrm{~mm}$ in height with its larval whorls ornamented by 6 spiral lines (figs. 3 and 4). The apical margin of the larval shell is thickened and accompanied by an anterior sinus (fig. 4). 
Larval shells from the Plankton of Aqaba of an unknown species closely resembling the larvae of Mecoliotia aqabaensis (figs. 5 and 6) but with one more larval whorl of the protoconch.

\section{Species Mecoliotia aqabaensis n. sp.}

Plate 2, figs. 5 and 6, Plate 3, figs. 1-4.

Derivatio nominis: This Mecoliotia comes from the Gulf of Aqaba at Aqaba and is named accordingly.

Diagnostic characters: The broadly conical shell has a protoconch with rounded whorls. The larval shell has spiral ornament of lines and rows of tubercles, consists of an initially smooth embryonic whorl and one larval whorl with spiral ornament which inserts in the final part of the embryonic shell. The teleoconch consists of 3.5 whorls and is ornamented by axial and spiral ribs forming a regular pattern of rectangles. The periphery is angular and the round aperture has a wide rim with fine lines. The umbilicus is conical. The shell is white.

Description: Its shell has an apical angle of about $80^{\circ}$ and is only $1.5 \mathrm{~mm}$ high and wide consisting of 3.5 whorls of the teleoconch. The whorls have a peripheral keel that remains as lowermost spiral rib on the whorls of the spire, while the spiral ribs of the base are covered by succeeding whorls. Their ornamented in the first whorls consists of one spiral rib near the suture, in the second whorl a second weaker rib appears apical to the main spiral rib and the third has three spiral ribs on the flattened upper side of the whorl. The first whorl has about 20 strong straight axial ribs, on the last there are about 30 axial ribs forming a regular pattern with the spiral ribs here. The flattened base is ornamented by eight spiral ribs on the last whorl, and also axial ribs that become weaker toward the umbilicus. The round aperture is surrounded by a thick rim ornamented in its outer side by fine rings and bulging to the side as strong varix.

The protoconch consists of a little more than two whorls and is about $0.3 \mathrm{~mm}$ high. The smooth embryonic shell is a little wider than $0.1 \mathrm{~mm}$ and ends with a sinuous first growth increment. The spiral ornament of the larval shell initiates on the last portion of the embryonic shell. The larval shell is ornamented by spiral rows of tubercles and spiral lines. Still on the last portion of the embryonic shell 6 spiral lines appear of which the fifth lies below the middle and is stronger than the other. The apical spiral lines grade into spiral rows of tubercles of which there are five on the final larval shell. The central one of these consists of larger tubercles than the other four. The keel-like strong spiral forms the apical margin of the projection of the outer lip. Below this keel three more spiral robs of tubercles are present and the ones on the base are covered up by the succeeding whorl. The aperture projects in a median lobe that is accompanied by an anterior sinus with thickened margin.

Remarks: MecoliotialMecoliotica (=Microliotia) was considered the genus to the subgenus Pickworthia [30]. Mecoliotia had also been interpreted to represent a subgenus of Sansonia, even a synonym to Sansonia by [5] [31] The type to the genus is Mecoliotia halligani Hedley, 1899 from Pacific Ocean near Funafuti Island ([3], fig. 1832) that has an angular corner to the base, as in case of Mecoliotia philippina Bandel \& 
Kowalke, 1997 ([12], pl. 4, figs. 4, 7). Mecoliotia aqabaensis resembles Mecoliotia philippina and both differ from each other by having the larval shell of half a whorl less while protoconch size is about the same ([12], pl. 4, figs. 4, 7). Mecoliotia aqabaensis has a few more axial ribs on each whorl of its teleoconch and may even represent only a variety to it. Mecoliotia philippina ([32], pl. 4, fig. 5) in contrast to Mecoliotia halligani has a lower, relatively wider spire. The apical angle of Mecoliotia aqabaensis is about $80^{\circ}$ and resembles Microliotia ohashii Kase, 1998. It differs from it by the ornament and shape of the base including the larger size of the umbilicus and also the protoconch has half of a whorl more. Regarding the angular basal periphery Mecoliotia ohashii is close to Microliotia mirabilis [33] but has a wider umbilicus.

Mecoliotia philippina Bandel \& Kowalke, 1997 is quite the same as a species called Clatrosansonia philippina ([5] 1998, fig. 2). Clatrosansonia Sabelli \& Taviani, 2003 was based on Clatrosansonia troendlei Le Renard \& Bouchet, 2003 and the genus was based on the species Mecoliotia philippina Bandel \& Kowalke, 1997 [5]. But Mecoliotia is better regarded as representing an independent genus.

Sherbornia Iredale, 1917 is characterized by a very much enlarged outer lip of its aperture when fully grown, but also similar ([5] [7], figs 15.101J,K). The genus Microliotia Boettger, 1901 has a circular aperture and is based on a species from the Miocene Paratethys ([13], pl. 1, fig. 1). It resembles Mecoliotia in regard to its triangular outline but has a more cancellate ornament and higher and relatively more narrow shell with apical angle less than $60^{\circ}$. Transitional between these two would be for example Microliotia fenstrata Kase, 1998 from Palau ([9], figs 11,12). It is slenderer than the type is also Microliotia alvanioides Le Renard \& Bouchet, 2003 from the Marquesas in the Pacific Ocean. The genus

Mareleptopoma is based on Mareleptopoma karpatensis from the Caribbean Sea and its resembles Sansonia especially when the fossil species are taken into consideration that have been placed in this genus by [13] and it resembles Microliotia brandenbergi Boettger, 1901. Living species fit in the diagnosis of the genus Microliotia in having a reticulate ornament dominated by axial ribs, and the base covered by more than 5 spiral ribs and an apical angle less than $60^{\circ}$ [9]. The genus Ampullosansonia Kase, 1999 has a shell that is less than $2 \mathrm{~mm}$ large with up to four rounded whorl of the teleoconch bearing ornament of axial ribs. The aperture is large and round with thickened lip. It has the characteristic protoconch of the family Pickworthiidae with one embryonic whorl and 1.5 larval whorls with spiral ornament. Ampullosansonia resembles Mareleptopoma.

In both Mecolitia and Microliotia usually the corner to the base of the teleoconch whorls is angular, in case it being more rounded species of the genus Sansonia and those of Reynellona Iredale, 1917 is similar. The latter usually has the shell is slender pointed ovate in shape, if more rounded ovate they are considered to belong to Ampullosansonia, and in case whorls are shouldered is would be Tinianella Kase, 1999 ([11], figs. 1-13). Reynellona with axial ribs is quite characteristic, in case it has also a few spiral ribs there are transitions to Sansonia (for example Reynellona granulata Kase, 
1998 and Reynellona semipellucida Kase, 1998 [8], figs. 5, 6, 13, 14).

The teleoconch of Mecoliotia also differs substantially from that of Pickworthia and Sansonia by being lower and provided with a strong apertural rim ([3], fig. 1832), and similar species have been placed in the genus Microliotia $(8,9)$. The difference of Sansonia to Mecoliotia can be noted regarding the shape of the umbilicus ([30] [31], figs.1832, 1833) while the details of the protoconch were not noted. The genus Mecoliotia is based on a living snail from the Austral-Asian region, and the genus Microliotia is based on a fossil snail from the middle Miocene of Romania ([3], fig. 1728). Quite similar modern species living in tropical submarine caves of the Pacific [9]. Sansonia has also been included in the genus name Mareleptopoma [26]. But this Mareleptopoma Moolenbeek \& Faber, 1984, that is based on Mareleptopoma karpatensis is problematic and some new species of Mareleptopoma from the Badenian (early Late Miocene) differing from each other by characters of the teleoconch [13] could fall into the variability of the one species Sansonia cebuana as described from Aqaba.

\section{Plate 4}

The slender shell of Crystella fincki consists of 5 whorls with the protoconch consisting of three whorls. $1.2 \mathrm{~mm}$ high teleoconch (figs. 2 and 4) are ornamented by a median keel with flattened upper and lower side; the upper a little wider than the lower. A second spiral rib lies in the suture and the three spiral ribs on the base are covered by succeeding whorls. A fine pattern of grains is arranged in fine spiral lines. The protoconch (figs. 3, 5 and 6) is approximately $0.2 \mathrm{~mm}$ high with smooth embryonic whorl that is almost $0.1 \mathrm{~mm}$ wide. Larval whorls have ornament of spiral ribs, the upper of which forms a ribbon of short axial ribs and there are two more such rows further down. The outer lip of the larval shell has projection and deep apical sinus with upturned margin (figs. 1, 3 and 6).

\section{Genus Chrystella Laseron, 1957}

Diagnostic characters: Shell shape slender and conical with protoconch of the shape as in Sansonia cebuana but with different ornament.

The genus is based on Chrystella islandica Laseron, 1957 from Christmas Island with no protoconch known A species determined as Chrystella finckhi (Hedley, 1899) had originally been described from Funafuti Atoll and has been collected from the Egyptian Red Sea [7], fig. 15.101I). It could be related or the same species to the slender form from Aqaba. It was placed close to Microliotia (=Mecoliotia) and to species known of Chrystella and Chrystella finckhi (Hedley, 1899) originally found at Tutaga Islet, Funafuti (Tuvalu) and Chrystella islandica Laseron, 1956 from Christmas Island, Australia to possibly represent the same species. Chrystella bhikajeei Moolenbeek \& Mussai, 2010, Chrystella kathyae (Rolán, 1990) from Cuba, Chrystella multistriata Santos \& Franca, 2008 from Brazil and Chrystella verdensis (Rolán \& Rubio, 1999) from the Atlantic at the Cape Verde Islands are noted as well as fossil species from the Miocene of the Paratethys such as Chrystella steiningeri Janssen, 2004, Chrystella tenuilirata Janssen, 2004 [7].

Species Chrystella finckhi (Hedley, 1899) 
Plate 4, figs. 1-6.

Description: The shell consists of 5 whorls of the white teleoconch and has a brown protoconch consisting of three whorls. Shell shape is slender conical with apical angle of about $30^{\circ}$ and a height of $1.2 \mathrm{~mm}$. Ornament consists of a median keel with flattened upper and lower side, the upper side a little wider than the lower side. The second spiral rib of the ornament comes to lie in the suture. On the base three more spiral are developed which become covered by succeeding whorls and a short spiral lies on the outer side of the columella. The whorls are covered by a very fine pattern of grains arranged in fine spiral lines.

The protoconch has the same shape as that of Sansonia cebuana but differs in regard to the ornament of the larval shell. It is a little more than $0.2 \mathrm{~mm}$ high with the embryonic whorl smooth and less than $0.1 \mathrm{~mm}$ wide. The larval shell is ornamented by spiral ribs, the upper of which forms a ribbon of short axial ribs and there are two more such rows further down. The aperture of the larval shell is extended into a wide and shovel like projection of the outer lip accompanied by a deep apical sinus with upturned margin. Larval shells of exactly that type have been caught from the plankton just off the Marine Station of Aqaba.

While the whorls of the protoconch are rounded those of the teleoconch are flattened from the first whorl onwards. The strong spiral on the periphery is accompanied by indistinct spirals just below and above the suture. The base of the last whorl bears 4 additional spiral ridges. The aperture is round with a duplicated margin. A micro-sculpture of spiral threads composed of minute is present on the teleoconch which is white while the protoconch is brown.

\section{Species Chrystella shinaqi n. sp.}

\section{Plate 5, figs. 1-4.}

Derivatio nominis: Called in honor of Rafi Shinaq from Department of Earth Sciences Yarmouk University, Irbid.

Locus typicus. The species is not common in the crevices of the fringe reef in front of the Marine Station in Aqaba, living within shallow water.

Diagnosis: Each whorl of the teleoconch carries five spiral ribs, of which the lower two become covered by succeeding whorls, the second forms a keel like edge giving the whorls a crenate outline, and the third lies just above the suture. The protoconch has its larval whorls ornamented by five spiral rows of tubercles.

Description: The slender conical shell with 3.5 whorls of the protoconch and 5 whorls of the teleoconch and is $1.4 \mathrm{~mm}$ high and $0.8 \mathrm{~mm}$ wide. The protoconch has the embryonic whorl quite smooth with very fine granules and a width of about $0.1 \mathrm{~mm}$. The first larval whorl has sinuous growth lines with two, rapidly three spirals which consist of elongate granules. Two of the spirals develop axial knobs which later fuse with each other to form an irregular reticulate pattern. The basal portion has smaller spiral lines. The margin of the outer lip is thickened with a wide anterior sinus forming a varix. The apertural hook is included in the flat upper flank of the first whorl of the teleoconch. 
The teleoconch is ornamented with a spiral ridge below the suture, a strong spiral on the periphery and a spiral ridge above the suture. The base of the last whorl bears 3 additional spiral ridges. The aperture is round with a duplicated margin. A micro-sculpture of spiral threads composed of minute is present on the teleoconch which is white while the protoconch is brown.

Remarks: Chrystella shinaqi closely resembles Chrystella finckhi, but has above the spiral keel just below the middle of each whorl a spiral rib on the whorls of the teleoconch, that is not found in Chrystella finckhi. On the base there are three spirals of which the upper one comes to lie in the suture when a further whorl is formed. The protoconch is quite the same in shape, ornament and size in both species, and also teleoconch shape and size are the same. The aperture of the fully grown shell is thickened and forms a varix that is almost circular in outline. Its inner callus cover is smooth.

Comparison: Chrystella shinaqi is very close in shape to Chrystella steiningeri Janssen, 2004 from the Miocene of the Paratethys. The protoconch has 0.5 more whorls in the modern species and the apical angle of the fossil species is higher, about $40^{\circ}$ ([13], pl. 4, fig. 10). The protoconch of Chrystella bhikajeei from Mauritius is very similar in shape, size and ornament. It has the slender conical shell with 8 whorls and is $1.6 \mathrm{~mm}$ high and $0.9 \mathrm{~mm}$ wide ([34], figs. 1-3). The protoconch consists of 3.5 whorls with almost smooth embryonic whorl and the first larval whorl with spirals to which later short axial ridges are added and resemble that from Aqaba. In contrast to the two species from Aqaba the median peripheral spirals of the ornament on the teleoconch develops axial knobs. The base of the last whorl bears 4 additional spiral ridges. The aperture is round with a duplicated margin. A micro-sculpture of spiral threads composed of minute granules is present on the teleoconch which is white while the protoconch is brown. All these characters are also found on the shells of the individuals from Aqaba.

Chrystella bhikajeei agrees with Chrystella finckhi which differs in regard to the strong knobbed spiral while that of Chrystella islandica and Chrystella finckhi are smooth [34].

Plate 5

Chrystella shinaqi has the teleoconch whorls with five spiral ribs (figs. 1 and 4) is 1.4 $\mathrm{mm}$ high and $0.8 \mathrm{~mm}$ wide. The two lower ribs of the ornament become covered by succeeding whorls. The protoconch has its larval whorls ornamented by five spiral rows of tubercles (figs. 2 and 3 ).

The shell with 3.5 whorls of the protoconch and 5 whorls of the teleoconch and is 1.4 $\mathrm{mm}$ high and $0.8 \mathrm{~mm}$ wide. The embryonic first whorl is almost smooth and approximately $0.1 \mathrm{~mm}$ wide. Figs. 5 and 6 are Discrevina satondae with protoconch (fig. 5) and $1.5 \mathrm{~mm}$ high shell of five whorls (fig. 6). Teleoconch whorls are ornamented by axial ribs and a spiral rib at the corner. The protoconch consists of a little more than two whorls with spiral ribs as ornament on the larval whorl (fig. 5) and smooth embryonic whorl.

Chrystella bhikajeei from Mauritius has the slender conical shell with 8 whorls and is 
$1.6 \mathrm{~mm}$ high and $0.9 \mathrm{~mm}$ wide ([34], figs. 1-3). The protoconch consists of 3.5 whorls with almost smooth embryonic whorl and the first larval whorl with spirals to which later short axial ridges are added and resemble that from Aqaba. In contrast to the two species from Aqaba the median peripheral spirals of the ornament on the teleoconch develops axial knobs. The base of the last whorl bears 4 additional spiral ridges. The aperture is round with a duplicated margin. A micro-sculpture of spiral threads composed of minute is present on the teleoconch which is white while the protoconch is brown. All these characters are also found on the shells of the individuals from Aqaba.

Chrystella bhikajeei agrees with Chrystella finckhi which differs in regard to the strong knobbed spiral while that of Chrystella islandica and Chrystella finckhi are smooth ([19] [34], fig. 73 A, B) has an elongate pupa-like shell with the last whorl measuring less in diameter than the whorl before it. The ornament consists of axial ribs on the apical part of each whorl and spiral ribs on the apertural portion and base. The protoconch has the barrel shape of the Pickworthiidae and ornament of spiral lines on the larval shell. The aperture of the fully grown teleoconch is thickened and round.

Genus Discrevinia Laseron, 1957

The genus Discrevinia Laseron, 1957 with the type Discrevinia balba Laseron, 1957 from Christmas Island.

\section{Discrevinia satondae n. sp.}

Plate 5, figs. 5 and 6, Plate 6 figs. 1 and 2.

Diagnosis: The about $1.5 \mathrm{~mm}$ high shell consists of five whorls of the teleoconch of the shape as in the genus diagnosis. They are ornamented by axial ribs which end on the uppermost spiral rib that forms the edge to the base. The three spiral ribs on the base become covered by succeeding whorls with exception of the uppermost one. The protoconch consists of two whorls with spiral ribs as ornament on the larval whorl. The aperture of the fully grown shell is thickened and has concentric grooves in its rim.

Derivatio nominis. The species was extracted from sediment dredged from close to Satonda Island, Indonesia.

Locus typicus. The small gastropod lives among corals in the shallow sea near Satonda.

Description: The protoconch is barrel-shaped with smooth an rounded embryonic shell of about $0.1 \mathrm{~mm}$ in diameter. The larval whorl is ornamented by solid and rounded spiral ribs, of which four remain visible on the spire. It ends with a large apertural projection of the outer lip accompanied by a deep angular lobe apertural to it. The protoconch is less than $0.2 \mathrm{~mm}$ high. The first whorl of the teleoconch has a concave side and a keel forming the base and just above the deep suture. On the second whorl of the teleoconch the sides become flat and axial ribs appear. The third to fifth whorl of the teleoconch are rounded and ornamented by about 15 simple rounded axial ribs ending in the basal corner formed by the first spiral rib. Five spiral ribs sculpture the weakly convex base. The outer lip of the aperture is thickened and the rim continuous to the inner lip, so that the outline of the aperture is circular. The aperture is almost vertically oriented and its rim bears grooves, of which there are up to four of the inner side and only one on the outer side. 
Remarks: Quite similar shell shape is found in Reynellona marigondon Kase, 1998. It differs from Discrevinia satondae by having less deep sutures, a smaller aperture and more spiral lines on the base. Its protoconch is quite similar ([10], figs. 7-9). Regarding shell shape and concave sutures Microliotia pumilis Kase, 1998 is similar as well but differs by a little wider shell and finer ornament ([9], figs. 22-26). The type to the genus Discrevinia balba has the last whorl of its shell covered by spiral ribs, while earlier whorls resemble those of Discrevinia satondae.

Discrevinia Laseron, 1957 resembles the genus Reynellona Iredale, 1917 in shape but has dominantly spiral ornament ([7], fig. 15,101E). The fossil Chrystella tenuilirata Janssen, 2004 from the Miocene of the Paratethys is slender as Chrystella in general, but regarding ornament and rounded whorl shape similar to Discrevinia or Reynellona.

Reynellona differs from Sansonia by the shape of the aperture which is smaller in the final stage of growth in Reynellona. But that tendency is seen as well in Sansonia cebuana from Aqaba, when to an already fully grown shell more shell is added, as is shown on Plate 2, figs. 1-4. Reynellona has the type species Reynellona natalis Iredale, 1917 with ornament of axial ribs ([7], fig. 15,101H). Reynellona granulata Kase, 1998 and Reynellona semipellucida Kase, 1998 have a similar ornament of their teleoconch. The protoconch in case of Reynellona semipellucida closely resembles that of Sansonia cebuana but no ornament of short axial ribs in addition to the spiral lines ([10], fig. 12). The aperture may detach and have quite round shape resembling those of some specimens from Aqaba.

Reynellona regarding ornament of axial ribs ([3], fig. 1834 and [7], fig. 15,101H) resembles the fossil Sansonia hedegaardi Bandel \& Kowalke, 1997 from the Paleocene of Denmark with a similar ornament and similar protoconch ([12], pl. 5, figs. 2, 5). This Danian species with more elongate shape would also come quite close to modern Discrevinia, such as the Discrevinia satondae n. sp.

Tinianella Kase, 1999 with the type Tinianella tabulata Kase, 1999 from a submarine cave at Tinian in the Pacific Ocean ([11], figs. 11-13) has the whorls of the teleoconch tabulate and ornament consists of fine sinuous axial. The protoconch consists of more than three whorls with smooth embryonic shell and axially strongly ornamented larval shell. It was suggested that Tinianella is close to Mareleptopoma in size and shape differing by its angular shoulders and the wider umbilicus [11].

Family Aqabarellidae n. fam.

Diagnosis:

The protoconch consists of a smooth embryonic whorl connected to a strongly ornamented larval shell that ends with a thickened margin of its aperture. The missing projection of its aperture distinguishes the Aqabarellidae from Planaxidae-Fossaridae as well as from Pickworthiidae-Vanikoridaelobe in the outer lip of their aperture. The teleoconch is strongly ornamented with axial and spiral ribs and small and solid. The family is based on Aqabarella urdunensis n. sp. from the Gulf of Aqaba.

Plate 6

Discrevina satonda in figs. 1 and 2 with $1.5 \mathrm{~mm}$ high shell that consists of five whorls 
(fig. 1). Ornament is by axial ribs which end on the uppermost spiral rib that forms the edge to the base (fig. 1). The protoconch consists of two whorls with spiral ribs as ornament on the larval whorl (fig. 2).

Aqabarella pulchella (figs. 3-5) has a protoconch of more than three whorls with smooth embryonic shell that is $0.08 \mathrm{~mm}$ wide (fig. 4). The larval shell is ornamented by nodded axial ribs which split into two ribs below the periphery and continue as lines of nodes. The teleoconch consists of 1.2 whorls and its end is twisted down somewhat (fig. 3) and thickened. Aqabarella urdunensis (fig. 6) has a $0.1 \mathrm{~mm}$ large smooth embryonic shell that is succeeded by a larval shell with almost two whorls ornamented by weakly sinuous growth lines and collabral strong ribs and the teleoconch of 2.5 whorls with its aperture is thickened. Ornament consists of strong spiral ribs and rounded minor spiral ribs between them.

Genus Aqabarella n. gen.

Description: It fits with the type species Aqabarella urdunensis from Aqaba.

Species Aqabarella urdunensis n.sp.

Plate 6, fig. 6, Plate 7, figs. 1-6.

Derivatio nominis. Called according to the locality of its occurrence.

Locus typicus. The species is not common and occurs in the crevices of the fringe reef in front of the Marine Station in Aqaba. It lives within shallow water.

Diagnosis: The smooth embryonic shell measures $0.1 \mathrm{~mm}$ and is succeeded by a larval shell with almost two whorls ornamented by weakly sinuous growth lines and collabral strong ribs. Its aperture is thickened. The teleoconch has up to 2.5 whorls with a varix after two whorls. The aperture of the fully grown shell is thickened with continuous evenly rounded outer lip and weakly convex inner lip. Ornament consist of 6 strong spiral ribs of which only two are not covered by the body whorl and rounded minor spiral ribs between them. Narrow axial ribs cross these with regular spacing. The base has a slit like umbilicus.

Description: The embryonic shell has the simple groove and ridge pattern as is commonly found on embryonic shells of Cerithioidea and other lower Caenogastropoda [35], and is about $0.1 \mathrm{~mm}$ in diameter. It ends with the first growth lines and with onset of the ornamented larval shell. The larval shell has and radial pattern in which the ribs have different outline in the upper, the middle and on the lower side. Just below the suture regular short curving ribs are in alternation with flat smooth intermissions. These ribs end in small branches which continue in a larger or in two ribs, may also end. Result is a network on the rounded shoulder. Below stronger ribs are found which are more distant from each other than the ribs just below the suture. They form nodules when crossed by fine spiral lines which form a somewhat irregular network.

On the first whorls of the larval shell axial and spiral ornament forms a T-shaped pattern, which in the second larval whorl changes into the axial ribs crossed by fine lines. The base is patterned by similar ornament. The larval shell ends in a simple outer lip without projection, quite different from the usual case among Cerithioidea, Littorinioidea and Rissooidea. The protoconch is a little more than $0.3 \mathrm{~mm}$ high and wide.

Quite a number of specimen present of this larger species. The teleoconch is trochi- 
form with two to 2.5 whorls. The ornament consists of spiral ribs and the simple aperture lacks a siphonal canal. The umbilicus is open. Of the stronger spiral ribs the upper one is the strongest. Between it and the deep suture the first whorl has three, the second whorl 5 minor spiral ribs, all of them of rounded shape. Inter-space between first and second larger spiral has three to four minor spiral ribs, and the next two are separated by two minor ones and the basal be one miner one. The rib around the umbilicus appears nodular. The spiral ribs are crossed by a regular pattern of about 30 narrow relatively sharp collabral ribs. These form a varix a short distance from the margin of the aperture. There may be a varix after two whorl of the teleoconch have formed, and to such a shell another 0.3 whorls can be added again ending with a thickened margin of the aperture. The shell measures 1.0 to $1.4 \mathrm{~mm}$ in width and about the same in height.

Quite a number of specimen present of this larger species. The shell is trochiform with few whorls of the teleoconch. The ornament consists of spiral ribs and the simple aperture lacks a siphonal canal. The umbilicus is open.

Remarks: A shell resembling that of Haloceras regarding the teleoconch, but not regarding the protoconch (Bouchet \& Warén, 1991). The larval shell of Haloceras is described as being predominantly ornamented by simple spiral ribs, but in general shape they are low trochospiral as is the case here, but much larger ([36], fig. 1721). Also similar in regard to teleoconch shape is Alvania (Galeodina) as described by ([18], fig. 94A), but here the protconch has the characteristic stripes on the embryonic shell. The family Haloceratidae with several species of Haloceras and two species of Zygoceras are known from New Caledonia. Information of this family is restricted to [18] [37].

Plate 7

Aqabarella urdunensis has an almost smooth embryonic shell that measures $0.1 \mathrm{~mm}$ (fig. 4). The larval shell added to it consists of almost two whorls ornamented by weakly sinuous growth lines and strong ribs which follow the outline of the aperture (figs. 3, 5 and 6). The teleoconch consists of up to 2.5 whorls with a varix after two whorls (fig. 1). The aperture of the fully grown shell is thickened with continuous rounded outer lip and weakly convex inner lip (fig. 1). Teleoconch ornament is of 6 strong spiral ribs of which only two are not covered by the body whorl and rounded minor spiral ribs between them (figs. 2 and 5).

\section{Species Aqabarella pulchella n. sp.}

Plate 6, figs. 3-5.

Derivatio nominis. Called due to it pretty shell.

Locus typicus. The species is rare in the crevices of the fringe reef in front of the Marine Station in Aqaba, living within shallow water.

Only two specimens were encountered. There is a relatively large protoconch in a relatively small shell with low spire.

The protoconch consists of more than three whorls with smooth embryonic shell and axially strongly ornamented larval shell. The embryonic shell is only about $0.08 \mathrm{~mm}$ wide and smooth. The larval shell is ornamented by nodded axial ribs which split into two ribs below the periphery and continue as lines of nodes. Between these ribs the 
shell is wrinkled spirally. The apertural margin is much thickened and its lobe, if present, is covered by the first teleoconch whorl. This teleoconch consists of only 1.2 whorls and its end is twisted down somewhat and thickened. It is ornamented by three strong spiral ribs forming keels and by numerous straight axial ribs crossing these.

Remarks: The shell of Aqabarella urdunensis resembles that of Haloceras regarding the teleoconch, but not regarding the protoconch. The larval shell of Haloceras is described as being predominantly ornamented by simple spiral ribs, but in general shape they are low trochospiral as is the case here, but much larger ([36], fig. 1721). Also similar in regard to teleoconch shape is Alvania (Galeodina) as described by ([18], fig. 94A), but here the protoconch has the characteristic stripes on the embryonic shell as found among the Rissoidae. [38] suggested that the family Haloceratidae are known from Australia with several species of Haloceras and two species of Zygoceras are known from New Caledonia. Information of this family is restricted to [36]. The characteristic protoconch of the two species of Aqabarellidae from the Gulf of Aqaba resembles that of some fossil species, the oldest of which belong to the Pseudozygopleuridae Knight, 1930 and occurred during the Carboniferous and Permian [39] [40]. Also the Triassic Cassianozyga seelandica Bandel, 1991 that lives in the tropical reef environment of the Tethys Ocean has similar protoconch shape and ornament [32] [41] and also in the Jurassic Sea a species determined as Buvignierina had a similar protoconch [41].

\section{Conclusion}

A common species of gastropods with rather small shell occurs in the shallow environment next to the fringing reef of Aqaba with Sansonia cebuana Bandel \& Kowalke, 1997. Aside of this species of the genus Sansonia Jousseaume, 1892, also a species of the genus Mecoliotia Hedley, 1899 is present here newly decribed as Mecoliotia aqabensis n. sp., two species of the genus Chrystella Laseron, 1957 with Chrystella finckhi (Hedley, 1899), and the newly described Chrystella shinaqi n. sp. A similarity is noted with genus Discrevinia Laseron, 1957 of which from specimens that had been collected in the Australian Reef area the new species Discrevinia satondae n. sp. is described. A new family Aqabarellidae is proposed to include the two newly described species of the genus Aqabarella n. gen. with the two new species Aqabarella urdunensis n. sp. and Aqabarella pulchella n. sp. Their characteristic shell resembles that of Planaxis lineolata Gould, 1851 and some Cerithiidae close to several species of Cerithium Bruguiére 1789 and to Clypeomorus bifasciatum Sowerby, 1855. This paper may become one of a number of papers dealing especially with the value of the ornament and shape of the larval shell for classification and evaluation of the marine gastropods in Aqaba, Jordan.

\section{References}

[1] Bavay, A. (1917) Coquille des sables littoraux de divers pays. Journal de Conchyliologie, 63, 91-114.

[2] Bavay, A. (1922) Coquille des sables marins de l'Indo-Pacifique. Genre Sansonia Jous- 
seaume, Pickworthia Iredale et Mecoliotia Hedley. Journal de Conchyliologie, 66, 155-161.

[3] Wenz, W. (1938) Gastropoda, Teil I. In: Schindewolf, O.H., Ed., Handbuch der Paläozoologie, 1639 p, Band 6, Verlag Gebrüder Bornträger, Berlin, 1639 p.

[4] Moor, D.R. (1962) The Systematic Position of the Family Caecidae (Mollusca: Gastropoda). Bulletin of Marine Sciences of the Gulf and Caribbean, 12, 695701.

[5] Le Renard, J. and Bouchet, P. (2003) New Species and Genera of the Family Pickworthiidae (Mollusca, Caenogastropoda). Zoosystema, 25, 569-591.

[6] Landau, B. and Fortea, J. (2006) Sansonia italica Raffi \& Taviani, 1985, Junior Synonym of Mareleptopoma minor (Almera \& Bofill, 1898). The Presence of the Family Pickworthiidae Iredale, 1917 in the Early Pliocene of Iberia. Journal of Conchology, 39, 55-61.

[7] Bouchet, P. and Le Renard, J. (1998) Family Pickworthiidae. In: Beesley, P.L., Ross, G.J.B. and Wells, F., Eds., Mollusca, the Southern Synthesis, Fauna of Australia, Vol. 5, CSIRO Publishing, Melbourne, 739-741.

[8] Kase, T. (1998) The Family Pickworthiidae (Gastropoda: Caenogastropoda) from the Tropical Pacific Submarine Caves: Four New Species of Sansonia, Venus, 57, 161-172.

[9] Kase, T. (1998) The Family Pickworthiidae (Gastropoda: Caenogastropoda) from the Tropical Pacific Submarine Caves: Seven New Species of Mecoliotia, Venus, 57, 173-190.

[10] Kase, T. (1998) The Family Pickworthiidae (Gastropoda: Caenogastropoda) from the Tropical Pacific Submarine Caves: Five New Species of Reynellona. Venus, 57, 245-257.

[11] Kase, T. (1999) The Family Pickworthiidae (Gastropoda: Caenogastropoda) from the Tropical Pacific Submarine Caves: Ampullosansonia n. gen. and Tinianella n. gen. Venus, 58, 91-100.

[12] Bandel, K. and Kowalke, T. (1997) Systematic Value of the Larval Shell of Fossil and Modern Vanikoridae, Pickworthiidae and The Genus Fossarus (Caenogastropoda, Mollusca), Berliner Geowissenschaftliche Abhandlungen Reihe E Palaeobiologie, 25, 3-29.

[13] Janssen, R. (2004) The Family Pickworthiidae in the Middle Miocene of the Paratethys (Gastropoda: Caenogastropoda: Littorinoidea?). Courier Forschungsinstitut Senckenberg, 246, 169-186.

[14] Bandel, K. (2006) Families of the Cerithioidea and Related Superfamilies (Palaeo-Caenogastropoda, Mollusca) from the Triassic to the Recent Characterized by Protoconch Morphology, Including the Description of New Taxa. Freiberger Forschungshefte, C511, 59-138.

[15] Reid, D. (1998) Superfamily Littorinoidea. In: Beesley, P.L., Ross, G.J.B. and Wells, F., Eds., Mollusca, the Southern Synthesis. Fauna of Australia, Vol. 5B, CSIRO Publishing, Melbourne, 737-739.

[16] Bouchet, P. and Rocroi, J.P. (2005) Classification and Nomenclator of Gastropod Families. Malacologia, 47, 1-397.

[17] Dockery, D.T. (1993) The Streptoneuran Gastropods, Exclusive of the Stenoglossa, of Northeastern Mississippi. Bulletin of Mississippi Department of Environmental Quality Office of Geology, 129, 1-191.

[18] Ponder, W.F. (1985) A Review of The Genera of the Rissoidae (Mollusca: Mesogastropoda: Rissoacea). Records of the Australian Museum Supplement, 4, 1-221. http://dx.doi.org/10.3853/j.0812-7387.4.1985.100

[19] Ponder, W.F. and Warén, A. (1988) Appendix. Classification of the Caenogastropoda and Heterostropha-A List of the Family-Group Names and Higher Taxa. In: Ponder, W.F., Ed., Prosobranch Phylogeny, Supplement 4, Malacological Review, Supplement 4, 288-328. 
[20] Abbott, R.T. (1974) American Seashells. 2nd Edition, Van Nostrand Reinold, New York.

[21] Bouchet, P., Le Guyader, H. and Pascal, O. (2011) The "Making of" Santo 2006. In: Bouchet, P., Le Guyader, H. and Pascal, O., Eds., The Natural History of Santo. Patrimoines Naturels, Vol. 70, Museum National d'Histoire Naturelle, IRD, Marseille, Pro-Natura International Paris, 529-548.

[22] Janssen, R., Zuschin, M. and Baal, C. (2011) Gastropods and Their Habitats from the Northern Red Sea (Egypt: Safaga), Part 2: Caenogastropoda: Sorbeoconcha and Littorinimorpha. Annalen des Naturhistorischen Museums in Wien Serie A, 113, 273-509.

[23] Selli, R. (1973) Molluschi quaternari di Massaua e di Gibuti, In: Missione geologica dell'azienda generale Italiana petroli (AGIP) nella dancalia meridionale e sugli altipiani Hararini (1936-1938). Vol. 4: Documentazione paleontologica, parte seconda, Accademia Nazionale dei Lincei, Roma, 153-444, Pls 1-30.

[24] Kowalke, T. (1998) Bewertung protoconchmorphologischer Daten basaler Caenogastropoda (Cerithiimorpha und Littorinimorpha) hinsichtlich ihrer Systematik und Evolution von der Kreide bis rezent. Berliner Geowissenschaftliche Abhandlungen Reihe E, 27, 1-121.

[25] Ladd, H.S. (1966) Chitons and Gastropods (Haliotidae through Adeorbidae) from the Western Pacific Islands. Geological Survey Professioal Paper, 531, 1-98.

[26] Moolenbeek R.G. and Faber, M.J. (1984) Studies of West Indian Marine Mollusca. A New Gastropod Genus and Species from Bonaire, Netherlands Antilles. Uitgaven Natuurwet. StudKring Suriname, 114, 98-103.

[27] Raffi, S. and Taviani, M. (1985) Sansonia italic.n. sp.: First Evidence of Sansonia Jousseaue 1892 from the Mediterranean Pliocene (Gastropoda, Prosobranchia). Archiv für Molluskenkunde, 115, 279-286.

[28] Rolan, E. (1991) Sansonia italica Raffi \& Taviani, 1985 primera cita para la fauna de Cabo Verde. Noticiario SEM, 13, 43.

[29] Thiele, J. (1931) Handbuch der systematischen Weichtierkunde. I. 1-778. Gustav Fischer Verlag, Jena.

[30] Thiele, J. (1929) Handbuch der systematischen Weichtierkunde. I. 1-778. Gustav Fischer Verlag, Jena.

[31] Wenz, W. (1939) Gastropoda. In: Schindewolf, H.O., Ed., Handbuch der Paläozoologie, Borntraeger, Berlin, (6)1: 1639 p.

[32] Bandel, K. (1991) Character of a Microgastropod Fauna from a Carbonate Sand of Cebu (Philippines). Mitteilungen aus dem Geologisch-Paläontologischen Institut der Universität Hamburg, 71, 441-485.

[33] Kuroda, T. and Habe, T. (1991) Recent Marine Mollusca of Japan. Leo W. Stach, Tokyo.

[34] Moolenbeek, R.G. and Musei, P. (2010) A New Chrystella from Mauritius (Gastropoda: Pickworthiidae). Miscellanea Malacologica, 4, 5-7.

[35] Bandel, K. (1974) Embryonalgehäuse karibischer Meso- und Neogastropoden (Mollusca). Akademie der Wissenschaften und Literatur, Abhandlungen der Mathematischen- Naturwissenschaftlichen Klasse. Jahrgang, 1-133.

[36] Waren, A. and Bouchet, P. (1988) A New Species of Vanikoridae from the Western Mediterranean, with Remarks on the Northeast Atlantic Species of the Family. Bollettino Malacologico, 24, 73-100.

[37] Bouchet, P. and Warén, A. (1991) Mollusca Gastropoda: Systematic Position and Revision of Haloceras Dall 1889 (Caenogastropoda, Haloceratida fam. nov.). ln: Crosnjer, A. and Bouchet, P., Eds., Résultats des Campagnes MUSORSTOM, Volume 7, Mémoires du 
Muséum National D'histoire Naturelle, Paris, 133: 457-499.

[38] Ponder, W. (1998) Superfamily Vanikoroidea. In: Beesley, P.L., Ross, G.J.B. and Wells, F., Eds., Mollusca, the Southern Synthesis, Fauna of Australia, Vol. 5B, CSIRO Publishing, Melbourne, 769-772.

[39] Nützel, A. (1998) Die Stammesgeschichte der Ptenoglossa (Gastropoda). Berliner Geowissenschaftliche Abhandlungen E, 26, 1-229.

[40] Bandel, K. (2002) Reevaluation and Classification of Carboniferous and Permian Gastropoda Belonging to the Caenogastropoda and Their Relation. Mitteilungen Geologie-Paläontologie Institut der Universitat Hamburg, 86, 81-188.

[41] Bandel, K. (1993) Caenogastropoda during Mesozoic Times., Proceedings of the Symposium Molluscan Paleontology, Scripta Geologica, Special Issue 2, Leiden, 7-56. 


\section{Appendix}

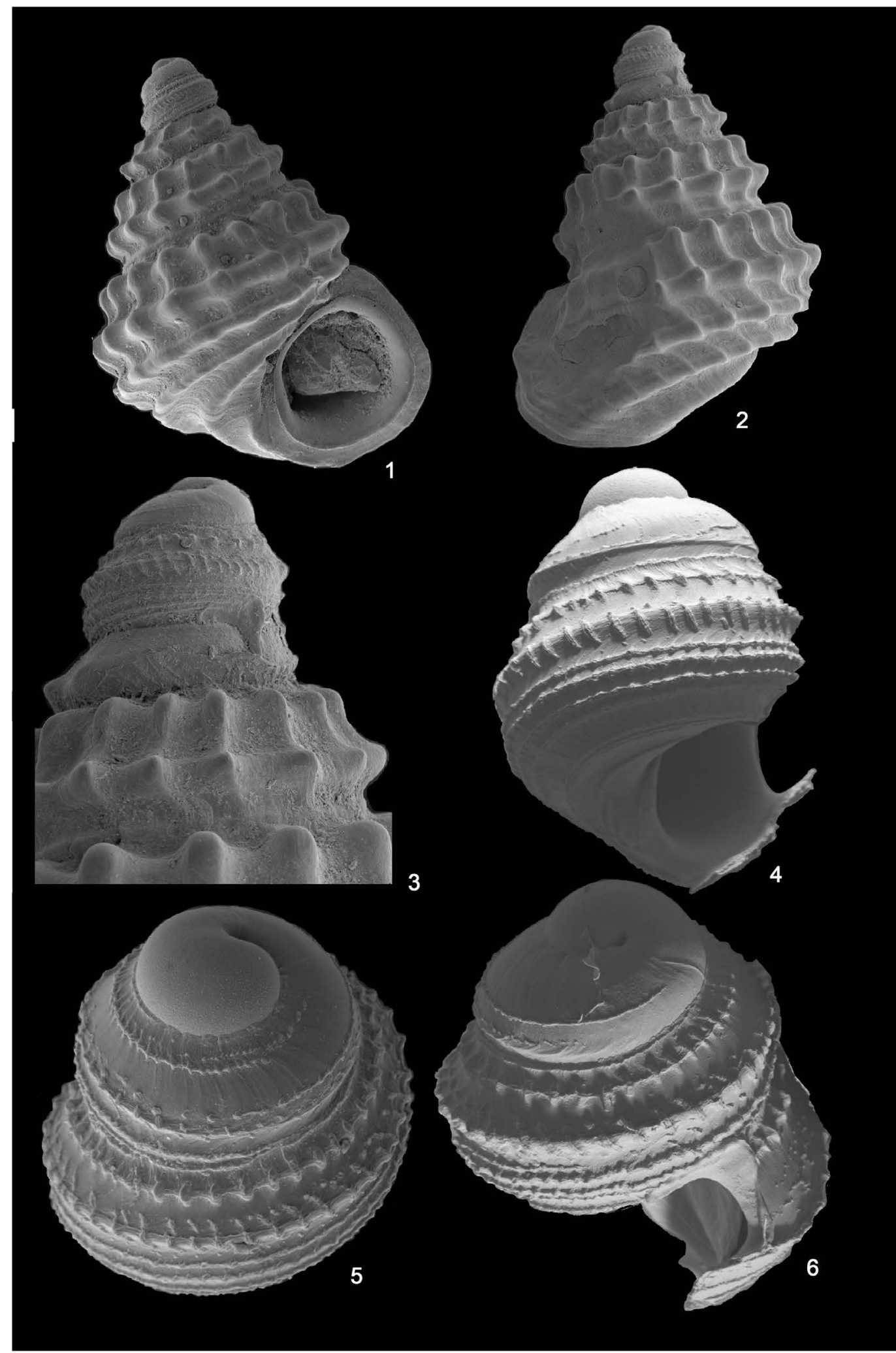

Plate 1 


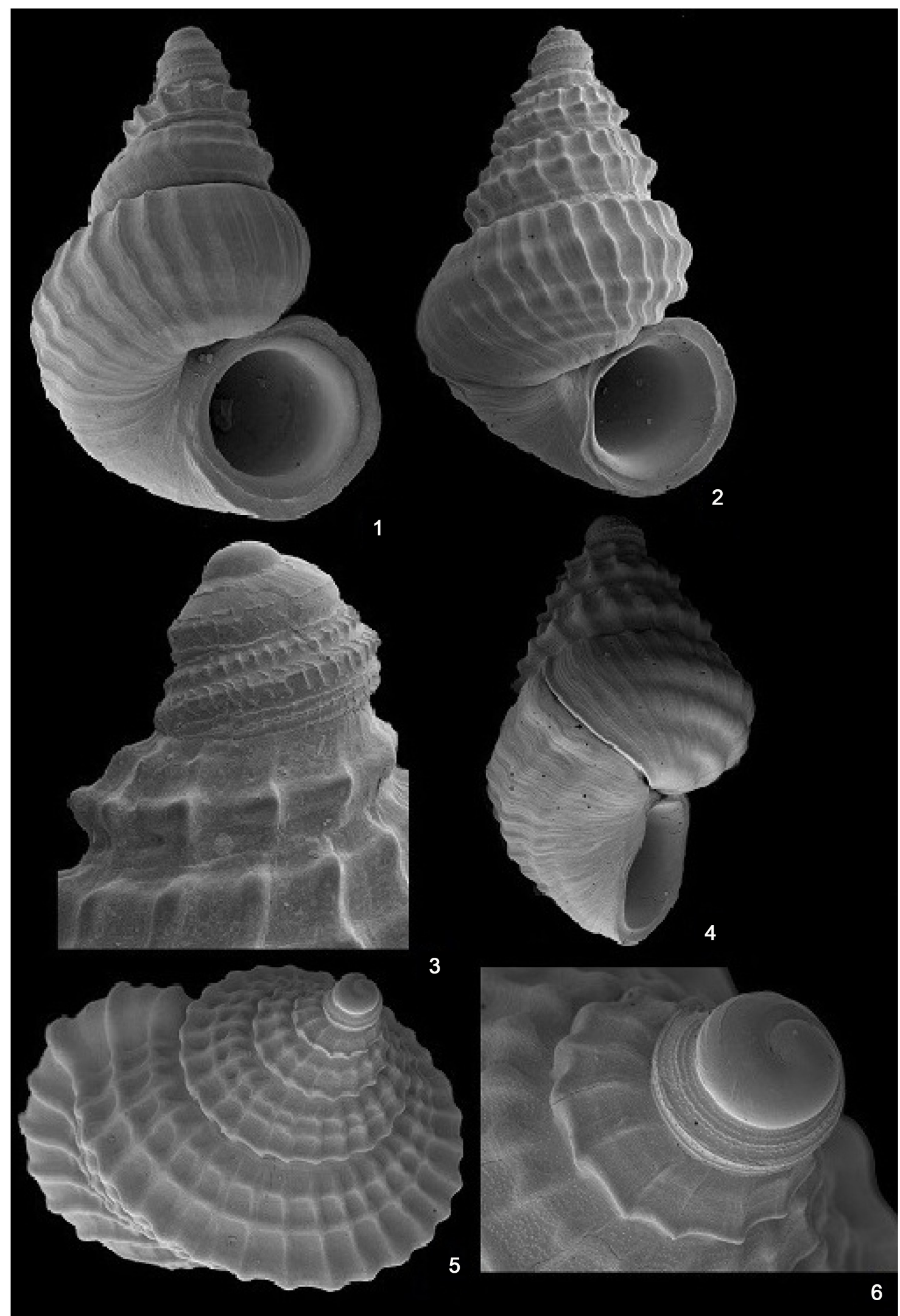

Plate 2 


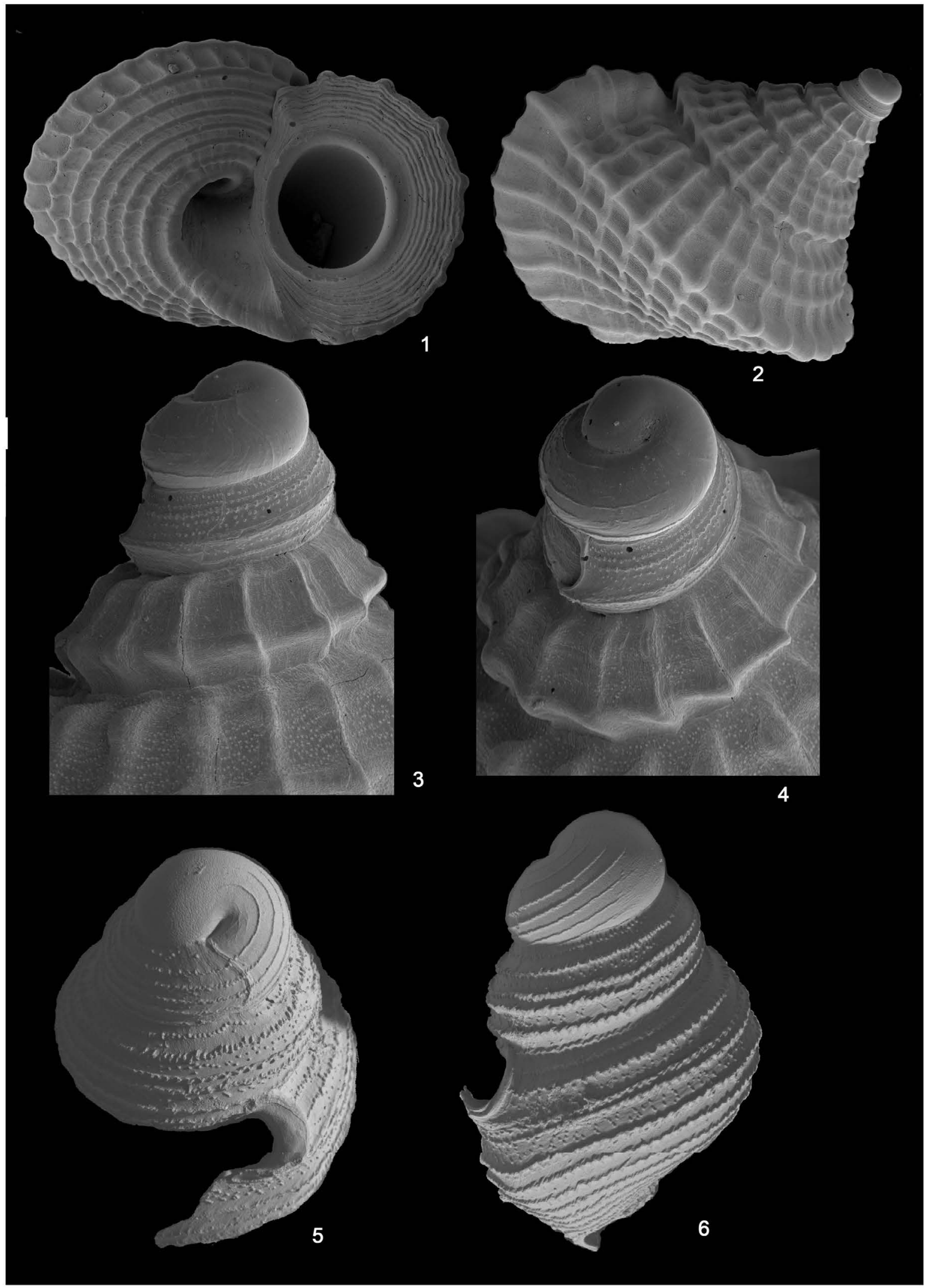

Plate 3 


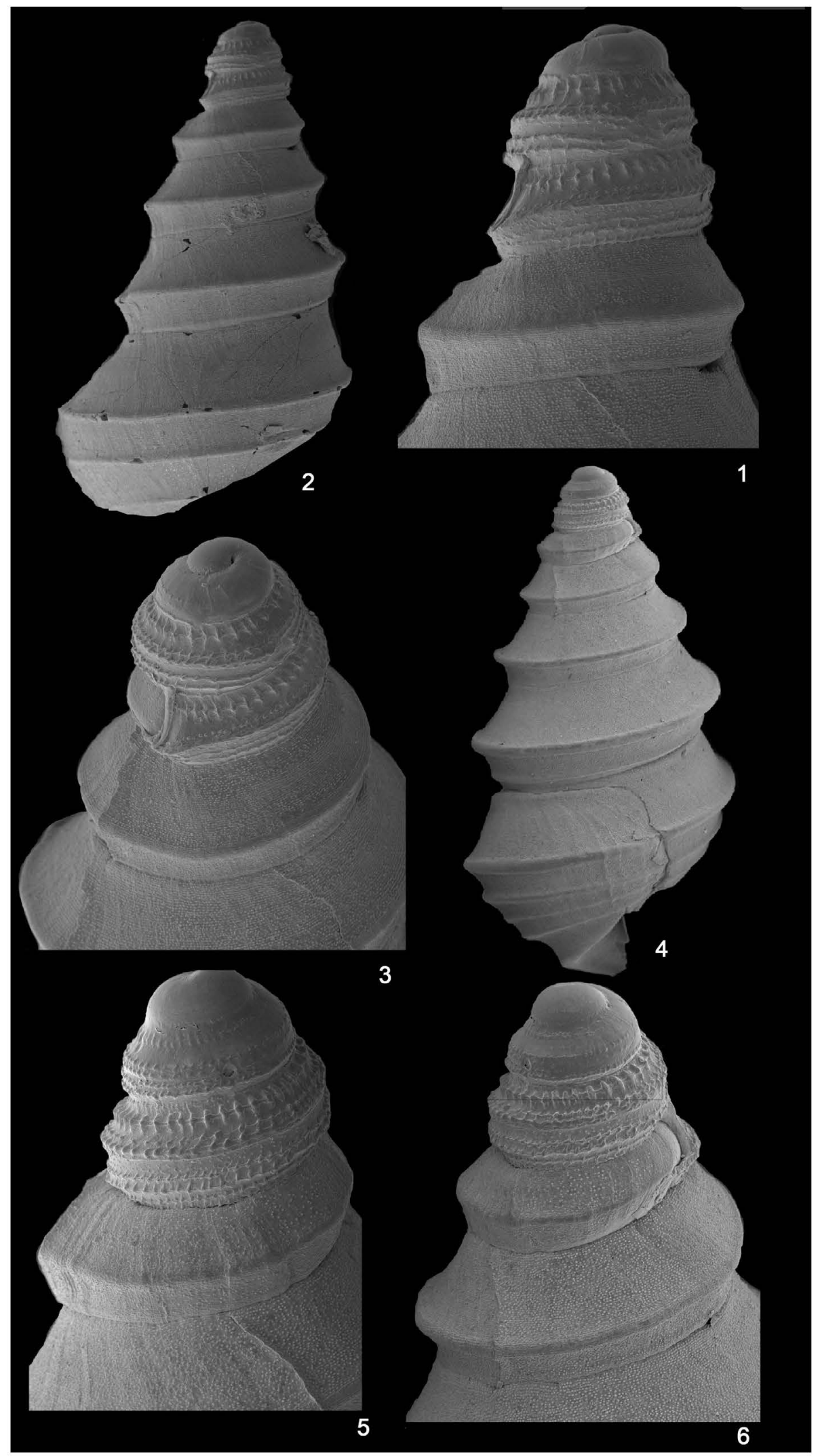

Plate 4 


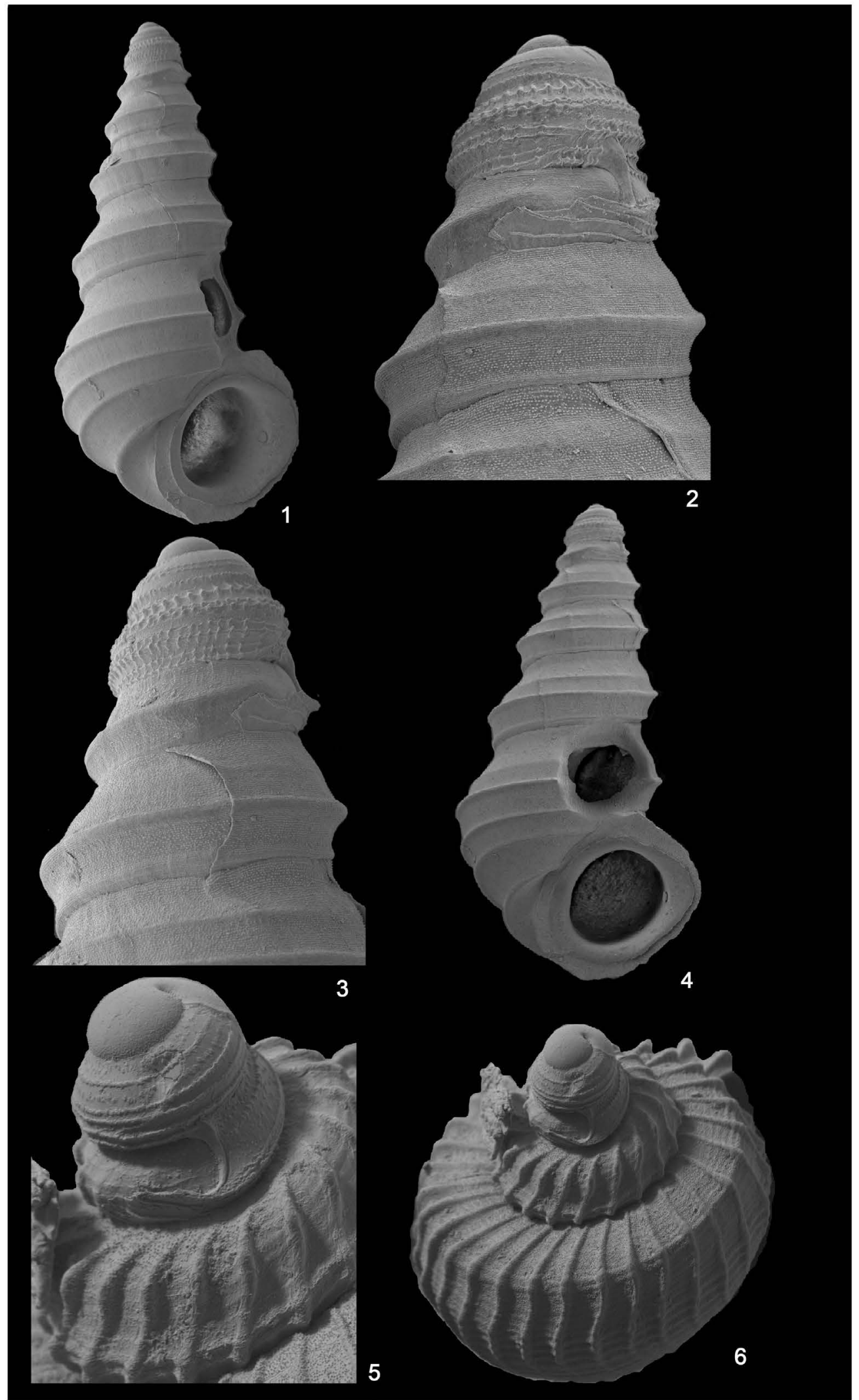

Plate 5 


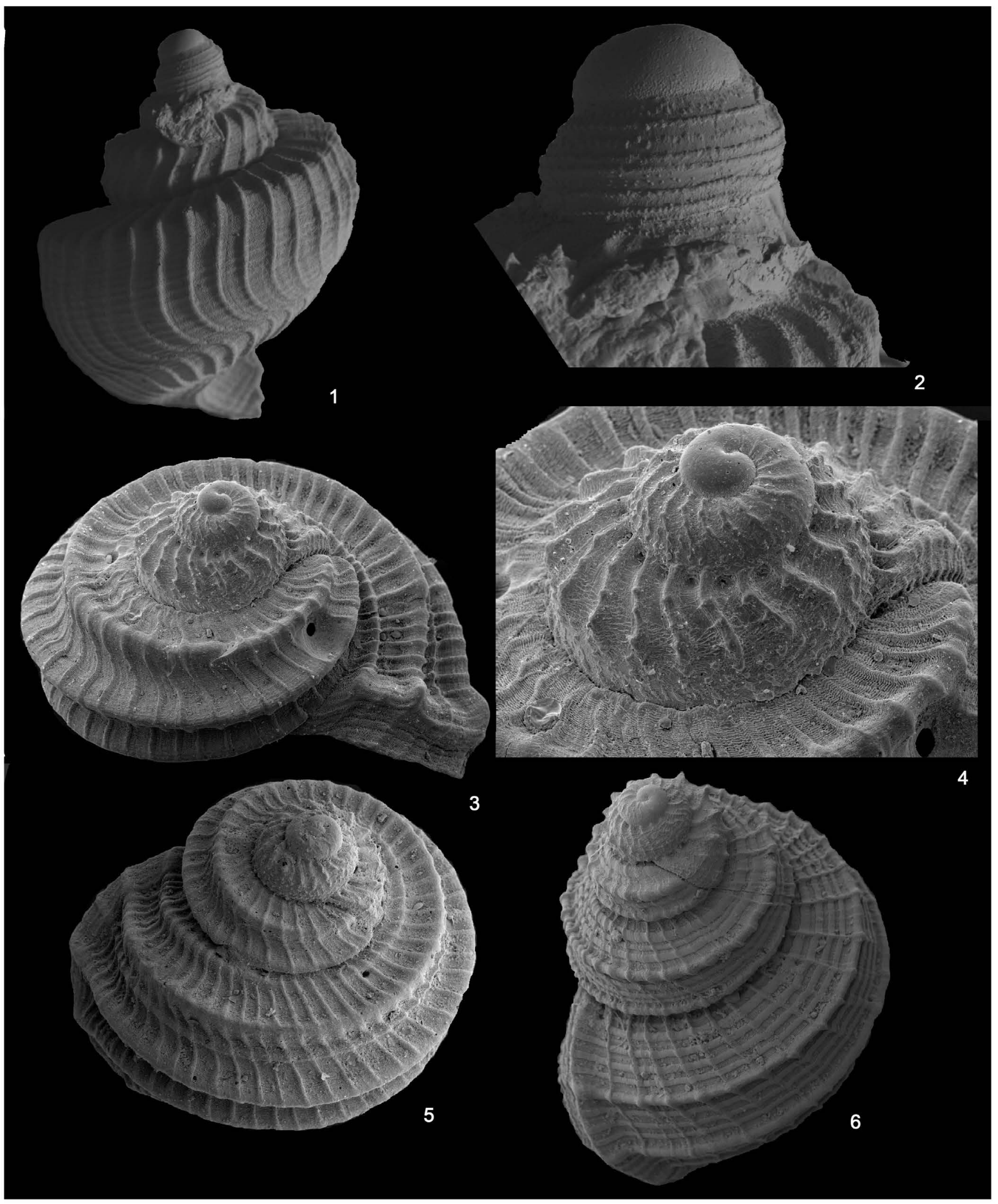

Plate 6 


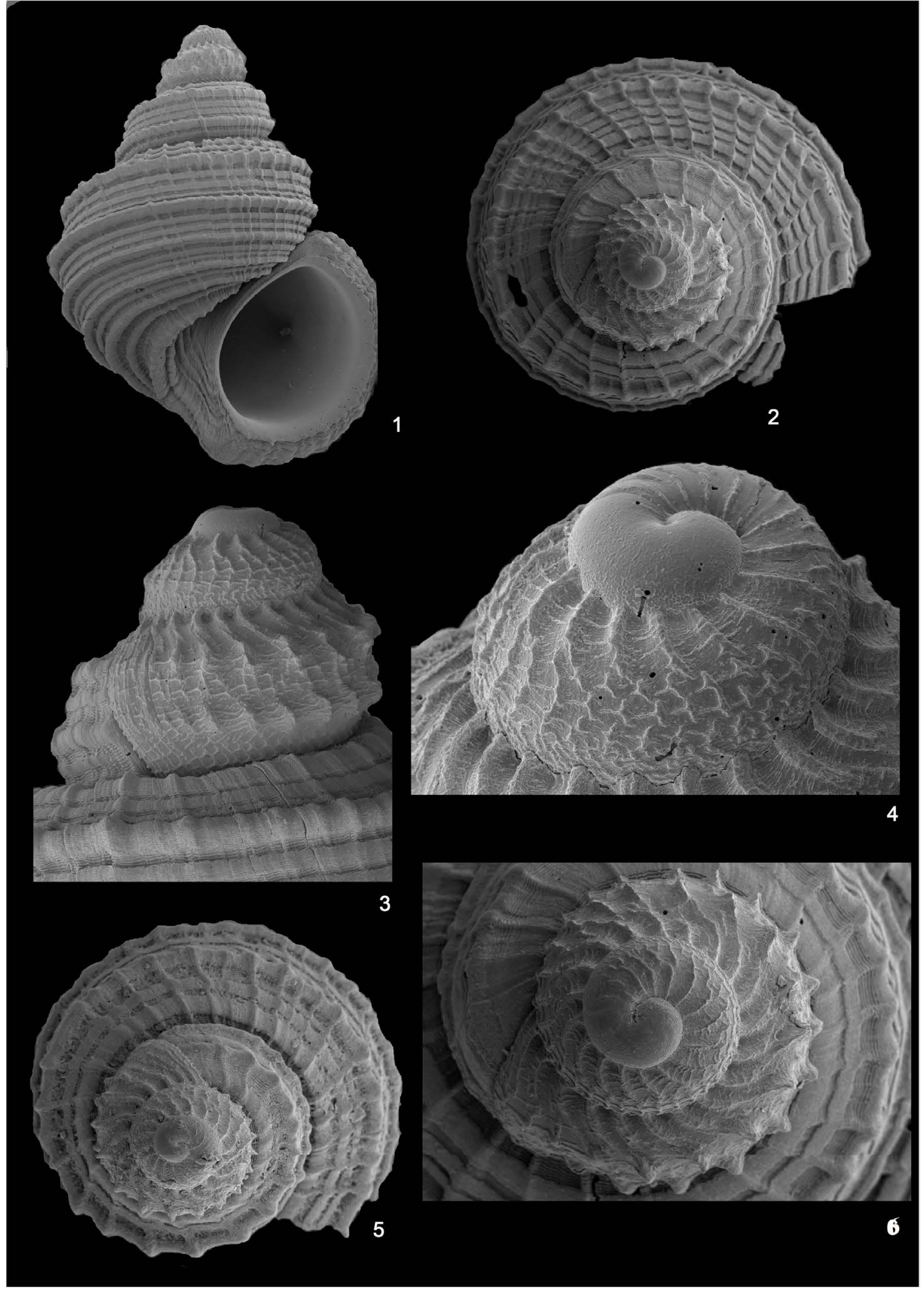

Plate 7 